\title{
LÍNGUA EM VIAGEM NA TRADUÇÃO DO DESENVOLVIMENTO SUSTENTÁVEL PARA EMPRESÁRIOS DO BRASIL E DE PORTUGAL: O CASO DO WBCSD
}

\section{LANGUAGE IN TRAVEL IN THE TRANSLATION OF SUSTAINABLE DEVELOPMENT FOR BUSINESSMEN IN BRAZIL AND PORTUGAL: THE CASE OF THE WBCSD}

\section{Robson Malacarne* Janette Brunstein ${ }^{*}$}

\section{RESUMO}

O propósito deste artigo é estudar a língua em viagem na tradução do desenvolvimento sustentável para empresários do Brasil e de Portugal. O World Business Concil for Sustainable (WBCSD), entidade foco deste estudo, atua no percurso de significação com a publicação de guias que visam orientar o discurso de gestão sustentável no ambiente corporativo. $\mathrm{Na}$ pesquisa analisou-se a disputa de poder que ocorre na definição do conceito de desenvolvimento sustentável (DS) e se propôs a metáfora think tanke como modo de traduzir a relação dos empresários com a questão socioambiental. A análise dos discursos, a luz da desconstrução de Derrida, permitiu estudar as estruturas políticas e institucionais que facilitam e dificultam a acolhida da discussão de desenvolvimento sustentável. Essas estruturas foram desenvolvidas na "história do pensamento ocidental", seja por meio de "textos filosóficos", ou em "formas e instituições tais como o governo, a universidade, a identidade nacional, o conceito de dom ou a ideia de enlutamento" (WOLFREYS, 2009, p. 51). Há o luto da presença, o luto da razão, o luto do sujeito e o luto de qualquer instância soberana (DERRIDA, 2013, p. 105). Verificou-se que a metáfora da Empresa Sustentável, desenvolvida neste processo de tradução, é insuficiente para acolher as diversas interpretações já que o intuito é assimilar e integrar. Na metáfora think tanke, por sua vez, reconhece-se a língua em viagem que demonstra as contradições e ambiguidades do discurso do WBCSD e acolhe as diversas traduções sobre DS. Assume-se um pensamento de alteridade que se traduz na desconstrução da relação entre hóspede (questão socioambiental) e hospedeiro (empresa). O hospedeiro torna-se refém das imprevisibilidades do hóspede (alterações

\footnotetext{
* Instituto Federal do Espírito Santo, IFES, Viana, ES, Brasil. robson.malacarne@ifes.edu.br

Orcid: https://orcid.org/0000-0002-6085-7853

** Universidade Presbiteriana Mackenzie, São Paulo, SP, Brasil janette@mackenzie.br Orcid: https://orcid.org/0000-0002-9019-3349
} 
climáticas, disponibilidade de água, biodiversidade etc), já que o "hospedeiro torna-se hóspede do hóspede" (DERRIDA, 2003, p. 109).

Palavras-chave: desconstrução; metáfora; língua em viagem.

\section{ABSTRACT}

The purpose of this article is to study the language in travel in the translation of sustainable development for businessmen from Brazil and Portugal. The WBCSD, the entity that is the focus of this study, acts in the route of meaning with the publication of guides that aim to guide the discourse of sustainable management in the corporate environment. The survey analyzed the power struggle that occurs in the definition of the concept of sustainable development (SD) and proposed to think tanke metaphor as a way to translate the relationship of business with social and environmental issues. The analysis of the discourses, in the light of the deconstruction of Derrida, allowed to study the political and institutional structures that facilitate and hinder the reception of the discussion of sustainable development. These structures were developed in the "history of Western thought," either through "philosophical texts", or "forms and institutions such as government, university, national identity, the concept of gift or the idea of grieving" (WOLFREYS, 2009, p. 51). There is the mourning of presence, the mourning of reason, the mourning of the subject and the mourning of any sovereign authority (DERRIDA, 2013, p. 105). The metaphor of the Sustainable Company, developed in this process of translation, was found to be insufficient to accommodate the different interpretations since the intention is to assimilate and integrate. The think tanke metaphor, on the other hand, recognizes the language in travel that demonstrates the contradictions and ambiguities of the WBCSD's discourse and welcomes the diverse translations on SD. It assumes a thought of alterity that translates into the deconstruction of the relation between guest (socio-environmental question) and host (company). The host becomes hostage to the vagaries of the guest (climate change, water availability, biodiversity etc), as the "host becomes the hostage of the guest" (Derrida, 2003, p. 109).

Keywords: deconstruction; metaphor; language in travel.

\section{INTRODUÇÃO}

A discussão sobre a metáfora como língua em viagem na tradução do desenvolvimento sustentável para o ambiente corporativo desenvolveu-se na literatura (BERNARDO, 2007; SPRINGETT, 2003; STAHEL, 2013) como também em iniciativas de think tanks com atuação internacional (LANS, BLOCK e WESSELINK, 2013; STONE, 2015). Há por trás desse movimento a ideia de que é necessário criar metáforas e jogos de linguagem para promover mudanças no percurso de significação e no estatuto da empresa (HEUSER, 2008). Do ponto de vista das macro iniciativas neste campo, um ator que desponta com o propósito de colaborar com esse processo de tradução é o World Business Council for Sustainable Development (WBCSD), foco deste estudo.

A atuação do WBCSD se dá em um cenário de emergência e fortalecimento de organizações multilaterais (think tanks) na tradução da questão socioambiental 
para o ambiente corporativo. O WBCSD pode ser considerado um exemplo de think tank que atua na orientação para o Desenvolvimento Sustentável (DS), na medida em que busca organizar guias e cursos sobre sustentabilidade para facilitar a acolhida dessa discussão nas empresas. Justifica-se a escolha do WBCSD nesta pesquisa por sua relevância e forte penetração no cenário mundial, a entidade reúne em torno de sessenta conselhos empresariais nacionais e regionais e mais de duzentas empresas. O WBCSD é um fórum criado em 1992 pelo empresário suíço Stephan Schmidheiny com o objetivo de defender e traduzir, na Conferência das Nações Unidas sobre Meio Ambiente e Desenvolvimento Humano, realizada no Rio de Janeiro, os interesses e teses do segmento empresarial com relação à questão socioambiental. Reconhece-se, portanto, uma disputa de poder na definição do conceito de Desenvolvimento Sustentável (DS). Ciente desse conflito de interesses, a intenção deste trabalho é responder ao seguinte problema de pesquisa: As metáforas e ambiguidades dos discursos do WBCSD sobre desenvolvimento sustentável facilitam a acolbida dos empresários à questão socioambiental?

A análise dos discursos do WBCSD realiza-se a luz de Derrida (1999), o objetivo não é estudar o texto em si, mas a tradução que está sendo feita na trajetória (BERNARDO, 2001). Pode-se entender que os discursos de negócios, sob essa perspectiva, são permeados por metáforas que buscam controlar as traduções e significações (DERRIDA, 2013, p. 43-44). Derrida denomina esse processo como logocentrismo, pensamento centrado na confiança e na hierarquia do logos e desenvolvido com base em oposições, em que são criadas relações hierárquicas, servindo como referência para interpretações e traduções, a fim de controlar e centralizar o discurso (DERRIDA, 1973). A tradução pode ser entendida como uma experiência de leitura e criação de metáforas, na qual se procura inventar palavras para deslocar interpretações e abrir espaço para o movimento da língua em viagem (DERRIDA, 1997). Esse movimento abre os conceitos ao pensamento da desconstrução, em que o processo de tradução é experimentado.

Compreende-se as estruturas políticas e institucionais que permeiam os discursos e os percursos de significação do WBCSD como lugar de metáforas, ambiguidades, contradições, limites e potencialidades. Neste estudo, a metáfora é lida como língua em viagem e desconstrói a ideia de que há um modelo prévio com a interdição das referências de tradução. Essa interdição (interrupção, limite, epoché) ocorre como pensamento da alteridade, do evento ou do porvir, que metaforiza a própria desconstrução como movimento de língua em viagem (BERNARDO, 2007). Diante dessa condição, este artigo pretende apresentar três contribuições principais: a) Propor a metáfora think tanke, como língua em viagem, para traduzir 
e repensar a relação das empresas com a questão socioambiental ${ }_{i}$ b) Estudar as estruturas políticas e institucionais que facilitam e dificultam a acolhida das questões socioambientais nas empresas; c) discutir as metáforas e as ambiguidades do discurso do WBCSD à luz da Desconstrução de Derrida.

\section{DESCONSTRUÇÃO E METÁFORA COMO LÍNGUA EM VIAGEM}

Cooper e Burrel (1988) expõem o pensamento de Derrida a partir de uma condição pós-moderna da compreensão da realidade. Uma das características deste modo não moderno de pensar a realidade é o enfoque dado aos pequenos relatos e interpretações, o que se valoriza são as traduções e as singularidades locais, não se busca o desenvolvimento de grandes narrativas que expliquem os comportamentos e as relações de maneira universal. Valoriza-se o movimento da língua em viagem que se configura de acordo com os acontecimentos locais e específicos (HEUSER, 2008).

O intuito deste movimento não é de substituição de uma metodologia com procedimentos estáveis por outra, não se busca o avanço para uma nova maneira de pensar a ciência, procura-se mais o deslocamento, o questionamento de instituições modernas que se desenvolvem a partir de pontos focais que definem os discursos, prejudicando o desenvolvimento de outras formas de linguagem e interação de perspectivas (CULLER, 1997). A compreensão da linguagem também é problematizada, mais do que um elemento neutro ou instrumental de comunicação, assume-se a característica da singularidade, para além da universalidade de uma linguagem que busca um discurso definitivo, o que se reconhece é um jogo de linguagens no qual as diferenças se relacionam por meio de um processo de alteridade, no qual o outro desestabiliza o centro e a origem da compreensão abrindo o discurso para diversas interpretações (HEUSER, 2008). Isso acontece devido à lei da ex-apropriação, que consiste em desmantelar a aparência de posse plena da língua, ou seja, para além da "apropriação como expropriação" (perder sua memória assimilando a memória do outro, uma se opondo a outra), o que ocorre é a apropriação interminável de um não próprio irredutível. A língua em viagem, portanto, apresenta-se como um não próprio irredutível, uma prótese de origem, na qual se busca, interminavelmente, se apropriar (ARAÚJO, 2015, p. 95).

A partir dessa leitura sobre a língua em viagem, como prótese de origem, visa-se desconstruir os conceitos nos quais se desenvolveu a metafísica ocidental: o fonocentrismo, o logocentrismo e o etnocentrismo (DERRIDA, 1973). Derrida (1973, p. 4) afirma que a história da metafísica "é a história de uma determinação 
do ser como presença" na qual a escrita assume o papel de representar a fala, que se revela como "logos", "verdade" e "origem" da escrita. O fonocentrismo, que é "voz" e é "fala", apresenta-se como "presença", e a escrita como "não presença" (SANTIAGO, 1976, p. 71). O logocentrismo, nesse sentido, "é uma metafísica etnocêntrica" (DERRIDA, 1973, p. 98) na qual a "verdade" é construída por meio de oposições, "presença" e "não presença", compreendida como contradições no processo de desconstrução do texto. Observa-se, portanto, que o caminho "platônico-aristotélico", representado abaixo, é rasurado, a hierarquia que privilegia o logos (razão, significado, logocentrismo) e compreende que o "signo existe para se apagar na sua referência ao significado" (fonocentrismo) é deslocada (DUQUEESTRADA, 2005, p. 254).

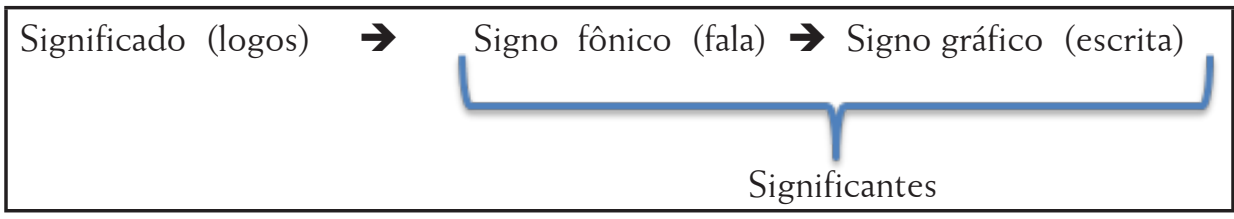

Figura 1. Relação entre significado e significantes.

Fonte: Autor, a partir da leitura de Duque-Estrada (2005).

Nesse sentido, a origem do significado não está fora do texto, a escrita não atua apenas para representar a fala (significante gráfico do significante fônico), o que se observa são relações de significantes, que se desenvolvem por meio de diferenciações, traços, textos, discursos e différance. Ou seja, com a desestabilização do centro, com a compreensão de que na tradução a origem é rasurada, e com o reconhecimento de que a linguagem é envolvida por um percurso de produção de metáforas e disseminação de sentidos, assume-se que "tudo se torna discurso" e aberto a leituras, rasuras e traduções (DERRIDA, 2002, p. 232).

Com essa perspectiva, o autor repensa as instituições e filosofias, com o intuito de relê-las por meio de seus espectros, de seus traços e rastros, de seus lutos e alteridades, compreendidos aqui como experiências da desconstrução da presença (DERRIDA, 2013, p. 105). Busca-se discutir as maneiras pelas quais as estruturas políticas e institucionais foram desenvolvidas na "história do pensamento ocidental", seja por meio de "textos filosóficos", ou em "formas e instituições tais como o governo, a universidade, a identidade nacional, o conceito de dom ou a ideia de enlutamento", (WOLFREYS, 2009, p. 51). O luto, portanto, é considerado singular pois é originário, não ocorre apenas no momento da perda mas é percebido como pensamento da alteridade, ou seja, vivencia-se o luto da presença, o luto 
da razão, o luto do sujeito e o luto de qualquer instituição e instância soberana (DERRIDA, 2013, p. 105).

Neste aspecto, Derrida (2002, p. 230-232) expõe suas críticas à metafísica ocidental por meio de sua discussão sobre o sentido do centro na estrutura e as possibilidades de se produzir um "descentramento" como forma de compreender o jogo que envolve esse processo de disseminação. $\mathrm{O}$ autor argumenta que a existência de um centro na estrutura "encerra o jogo que abre e torna possível" tranquiliza as incertezas, pois todas as suas possibilidades e alternativas são construídas a partir de um ponto de referência, o centro. Segundo o autor, ao optar por esse caminho, a "história passa a ser compreendida como um encadeamento de determinações do centro, que assume o papel de referência na constituição da estrutura". Assim, a desconstrução pode ser um modo de questionar as estruturas políticas e institucionais que criaram condições para a construção dos conceitos relacionados ao Desenvolvimento Sustentável (DS).

Kearins e Springett (2003), por exemplo, problematizam a temática do DS por meio da teoria crítica e dos conceitos desenvolvidos por Foucault. As autoras realizam um debate sobre a genealogia internacional do conceito de desenvolvimento sustentável, como foi construído e contestado durante o seu processo de evolução. Num primeiro momento Kearins e Springett (2003) afirmam que a teoria crítica e a perspectiva neomarxista apontam o nível de consumo e de produção, característicos da economia capitalista, como as causas para a crise global e ambiental. Essa perspectiva avalia que o avanço na discussão do conceito de desenvolvimento sustentável vem sendo controlado de modo a atender a interesses comerciais

Há, portanto, uma disputa de poder para definir o conceito de DS e seus desdobramentos. Isto se evidencia no discurso dos negócios, na medida em que não se discutem questões como exploração do povo e de recursos no ambiente empresarial. Para superar este controle, propõe-se a adoção de um processo dialético dinâmico que favoreça a compreensão de como o conceito de DS foi criado, por meio da análise dos controles ideológicos, políticos e epistemológicos relacionados à temática.

Springett (2003, p. 6) afirma que o termo DS é frequentemente substituído por sinônimos nas leis e documentos empresariais. Cita-se o exemplo do Triple Bottom Line (TBL) e do termo "sustentabilidade". A ferramenta TBL representa a aplicação da lógica da sustentabilidade no meio empresarial, ao defender a possibilidade de crescimento econômico integrado a responsabilidade social e responsabilidade ambiental. Baldissera e Kaufmann (2013) questionam o TBL 
como modo de traduzir o desenvolvimento sustentável para os empresários por não considerar a complexidade ecossistêmica do meio ambiente e a dependência do sistema econômico com a natureza, que disponibiliza recursos para a produção industrial, por exemplo. Como caminho, para superar essas incongruências, os autores defendem a desconstrução da racionalidade econômica, com mudanças que questionem os modos de produzir, consumir e viver.

Assim, assume-se que a utilização de sinônimos do DS, como TBL e sustentabilidade, buscam silenciar os questionamentos sobre a característica do consumo na sociedade capitalista, criando uma discursividade que instrumentaliza as necessidades humanas de modo a reduzi-las à necessidade de consumo. Tal instrumentalização pode ser verificada no relatório Nosso Futuro em Comum que buscou unir os conceitos de crescimento econômico, justiça social e integridade ambiental, e justificar a partir disso o foco no crescimento econômico como forma de alcançar a justiça social e se aplicar o conceito de DS (SPRINGETT, 2003).

Deste modo, a adoção da desconstrução de Derrida representa um movimento para repensar os discursos de Desenvolvimento Sustentável - DS, pois além de discutir o significado que este tema representa nas relações de trabalho nas organizações, ele possibilita questionar os elementos e contradições inerentes ao discurso empresarial. Assim, a leitura do texto a partir do outro, da alteridade, pode servir à análise da crise socioambiental, na medida em que não se busca definir a interpretação correta diante dos problemas socioambientais, o intuito é compreender os discursos e contradições que se revelam no ambiente empresarial, no qual se busca, constantemente, controlar as interpretações e traduções a partir de um centro produtor de metáforas, um think tank que dissemina conceitos para as empresas reproduzirem em seus negócios.

Outra discussão importante para Derrida (1978, p. 27), que colabora para o descentramento na análise dos discursos, é a différance, palavra inventada pelo autor para discutir e problematizar a relação entre linguagem e escrita. Isto ocorre, pois se promove a inserção do "a" na palavra différence, o que se observa é que a pronúncia em francês não se modifica e só se consegue perceber o "erro", praticado de maneira intencional, quando se confere a devida atenção à escrita. O logocentrismo, portanto, é questionado, na medida em que a hierarquia que privilegia o discurso sobre a escrita é deslocada.

Desse modo, essa metáfora de leitura, essa invenção denominada différance assume concomitantemente o diferir nos seus sentidos de temporização e espaçamento. A temporização se refere à ação de "remeter para mais tarde" o processo de significação. Desse modo, busca-se relacionar o rastro entre os 
elementos constituintes do "tempo e do espaço". Para alcançar esse intuito é preciso um intervalo, um espaçamento entre esses elementos, a fim de dividir e identificar no presente a "substância e sujeito", que são definições da língua metafísica (DERRIDA, 1978, p. 44)

Derrida (2001, p. 46) afirma que a "différance" encontra-se envolvida em um processo de espaçamento, que ela põe em movimento, por meio de uma cadeia de outros conceitos, de outras palavras, de outras "configurações textuais", tais como o rastro, a rasura, a marca e a margem, que se caracterizam como pontos focais nos quais o texto se desenvolve. Estes pontos focais, marcas do processo de espaçamento, são colocados em movimento pela différance. O rastro, neste percurso, cria uma comunicação com os elementos constituintes do "tempo e do espaço" e assume a responsabilidade de abrir a experiência da significação. Não se identifica, portanto, uma origem absoluta da significação, já que em todo o processo verificase a marca do rastro (WOLFREYS, 2009). Assim, "o rastro (puro)" é a différance que permite ao tempo e ao espaço articular-se na experiência (DERRIDA, 1973, p. 7780), e reencontrar nela o instante, a aporia, o evento da invenção.

Esse processo de significação, de decisão, de pensamento inventivo proporciona uma experiência de tradução, na qual ocorrem produções e disseminações de sentidos, desvios e deslocamentos que impedem a identificação do conceito original, cujos traços e rasuras revelam o modo de tradução metafórica do texto (DERRIDA, 1986). Assim, o que se busca analisar não é o texto em si, mas a leitura que está sendo feita do texto, a tradução singular que se realiza a partir da criação de metáforas explicativas, cuja interpretação se justifica por meio uma "alteridade absoluta", na qual a leitura do outro é considerada na experiência de compreensão do texto, proliferando os sentidos dos conceitos (NASCIMENTO, 2001). A invenção, neste sentido, são os discursos e metáforas que buscam "responder ao que vem antes de si, e diante de quem se está" (BERNARDO, 2001, p. 346). No entanto, não é possível dominar a viagem desse movimento de invenção.

Apesar de tradicionalmente a metáfora ser compreendida como oposição do próprio e do não próprio (sentido figurado), do visível e do não visível, do dia e da noite, assumindo o sol como paradigma que estrutura a língua filosófica, este trabalho reconhece, no percurso de análise, a metáfora como língua em viagem. A viagem não consiste em passar de uma língua para outra, ela passa a língua, através da língua, e para além. A metáfora como língua em viagem desconstrói a ideia de que há um modelo prévio a seguir com a interdição da propriedade. Essa interdição (interrupção, limite, epoche) ocorre como acolhimento incondicional do pensamento 
do outro, do evento ou do porvir que metaforiza a própria desconstrução como movimento de pensamento. Resiste-se, deste modo, a tentativa de domesticar e estabilizar a metáfora em uma classificação, o que acontece quando se busca conduzir a viagem com um caminho pré-estabelecido e com retorno programado ao lugar de origem, em um círculo logocêntrico. Assim, a metáfora como língua em viagem é assumida como sincategorema, um quase-conceito, um conceito incompleto ou aberto. Há, portanto, uma dissimetria absoluta da relação com a originalidade, com o próprio sendo metaforizado, deslocado e ex-apropriado (BERNARDO, 2007).

Ao pensar essa discussão em relação à sustentabilidade empresarial, reconhecese a questão do desenvolvimento sustentável como herança que exige respostas, ou seja, o "ser finito" precisa tomar decisões e planejar como conduzir os negócios considerando os impactos socioambientais. Todavia, o percurso de acolhimento a esta herança é pervertido pela linguagem, é marcada pelo traço, "como laço que, ao mesmo tempo, liga e desliga". Assim, ao abrir-se, sem condições, à estranheza do outro (qualquer outro: meio ambiente, animal etc), se lida com a finitude do ato performativo, com as condições necessárias à efetividade da hospitalidade, à concretude, que se revela no evento, como decisão (BERNARDO, 2001, p.395).

Esta hospitalidade, também compreendida "como um outro nome da desconstrução" (BERNARDO, 2005, p. 175), se encontra entre duas lógicas, a do "convite", que conserva o sentido do controle (leis da hospitalidade condicional), pois pressupõe condições (regras, estatutos e requisitos) para a acolhida do outro, e a "lógica da visita" (Lei da hospitalidade incondicional), que se abre a outras traduções e discursos, inesperados e imprevisíveis, na qual acolhe-se o "outro, na sua estranheza" (DERRIDA, 2004, p. 269). Reconhecer a estranheza do outro (qualquer outro: animal, meio ambiente, ser humano etc) é assumir a ideia do registro espectral que existe na desconstrução. Neste sentido, respeitar a alteridade implica dar espaço à dimensão espectral do outro, revelada como rastro, visto que o outro é um enigma, pois não se pode ter a pretensão de conhecê-lo e o apropriar, de conduzir e controlar suas interpretações (BERNARDO, 2001)

Destaca-se, no entanto, que não há uma relação de dicotomia entre "A Lei da hospitalidade, incondicional ou absoluta, e as leis da hospitalidade, condicionais e limitadas" o que se revela é uma antinomia não dialetizável e uma heterogeneidade sem oposição (BERNARDO, 2005, p. 206). Isso significa que a Lei da hospitalidade sem condições (visita) necessita inscrever-se na lógica do controle (convite) para tornar-se efetiva, não utópica e não abstrata. Da mesma forma a hospitalidade condicional é pervertida, guiada e inspirada pela hospitalidade incondicional reconhecendo suas insuficiências na busca pela justa acolhida. Há uma "estranha 
hierarquia" entre estes dois termos (heterogeneidade dissimétrica), a Lei está acima das leis, pois Ela (anômica; fora da lei) assume um ponto de vista crítico no que se refere ao instituído (estatuto, regras e leis), ao expor suas lacunas e limitações (DERRIDA, 2003, p. 71). Neste sentido, a cada passagem da Lei nas leis, abre-se uma aporia nas regras instituídas, uma brecha que possibilita meios para torná-las mais justas e acolhedoras. Derrida nós dá a pensar esta passagem com o termo/aporema "hos-ti-pi-talidade", isto é, ainda que a hospitalidade incondicional se inscreva nas normas da hospitalidade condicional, conserva-se um perfil de contraditoriedade, antinomia e indissociabilidade nessa relação (BERNARDO, 2005, p. 190).

Deste modo, acolhe-se o porvir das necessidades das gerações futuras, por meio de uma disseminação inventiva que se revela como différance, como hospitalidade incondicional, como feixe de compreensões cruzadas por diversas linhas de sentido (DERRIDA, 1978, p. 29). A metáfora da leitura, nesta perspectiva, é a abertura aos diversos discursos de sustentabilidade empresarial, de modo a ampliar as possibilidades de interpretações e rasuras, em um sentido de hospitalidade incondicional, atento, no entanto, às condições e requisitos exigidos pela hospitalidade condicional (DERRIDA, 2013, p. 43-44). Assim, desviam-se as referências de leitura, as dicotomias entre o que diz respeito às responsabilidades empresariais (ambiente interno) e às responsabilidades socioambientais (ambiente externo), ao ponto de compreendê-los como traços neste processo de disseminação e abertura ao pensamento da alteridade, ao discurso que se desenvolve nessa experiência de significação (DERRIDA, 2004, p. 17).

Deste modo, a questão socioambiental pode ser acolhida pelas empresas na lógica do convite ou na lógica da visita. Quando a acolhida se dá pela lógica do convite vive-se uma situação similar a do cidadão estrangeiro que precisa respeitar o estatuto, as leis e as normas do país para receber a hospitalidade adequada, e se integrar nesta sociedade. No entanto, quando a empresa reconhece na questão socioambiental o outro absoluto, assume-se uma postura de alteridade, acolhendo-a, sem condições. Esse pensamento da alteridade traduz-se na desconstrução da relação entre hóspede (questão socioambiental) e hospedeiro (empresa). Isso ocorre, pois o "hospedeiro torna-se hóspede do hóspede" visto que a hospitalidade incondicional torna o hospedeiro refém do hóspede (DERRIDA, 2003, p. 109).

Este percurso de tradução se vivencia a partir da rasura, do indecidível, o que evita cair na perspectiva do ser como presença, que integra a história da metafísica. A rasura é uma postura que é parte do movimento da différance e se constitui um dos pontos focais do percurso de espaçamento. Os indecidíveis, por sua vez, são "unidades de simulacro" (DERRIDA, 2001, p. 48-49) que desestabilizam a 
dicotomia e estabelecem novas relações, mas não é somente a oscilação ou a tensão entre duas decisões, [...] é a experiência daquilo que, estranho à ordem do calculável e da regra, deve, entretanto, [...] entregar-se ã decisão" (DERRIDA, 2010, p. 46).

Neste sentido, a tradução pode ser compreendida como uma experiência de leitura, na qual se busca perceber o que não foi lido na interpretação oficial das instituições. Leitura esta que é marcada por desvios de sentidos, desestabilizações, rastros, descentramentos, que possibilitam assumir, na experiência das traduções e leituras, o movimento da desconstrução. Este movimento abre os conceitos à experiência de significação, compreendida aqui como uma "metáfora da leitura", na qual os conceitos são rasurados, sendo traçados e traçando outros sentidos, na qual o processo de tradução é vivenciado num vir a ser infindável (FERREIRA; OTTONI, 2006, p. 32).

Neste "percurso" a desconstrução do texto ocorre por meio da "inversão" e do "deslocamento" (DERRIDA, 1973, p. 4;) A "inversão" propõe desconstruir as posições dicotômicas do texto, ou seja, "inverter a hierarquia" presente nas oposições; enquanto o "deslocamento" ocorre por meio da inserção de "marcas [...] indecidíveis", que evitam o equívoco de apenas "neutralizar as oposições binárias", mas também o "afastamento" da inversão, a fim de deslocar as oposições, utilizando-as no argumento de modo a the dar um impacto e uma condição diferentes (DERRIDA, 2001, p. 47-49). Nesse sentido, Derrida (1999, p. 108) compreende desconstrução como "uma tomada de posição, no próprio trabalho, no que diz respeito às estruturas político-institucionais que constituem e regulam nossa prática, nossas competências e nossos desempenhos".

Essas estruturas políticas e institucionais podem assumir uma forma constatativa e performativa no cotidiano das organizações, não de maneira dicotômica, mas sob uma perspectiva de indecidibilidade, na qual a responsabilidade pela busca da verdade (teórica e constatativa) e pela prática (ação e performativa) é difícil de delimitar, já que seu desenvolvimento é marcado por lacunas e aporias (DERRIDA, 2003). Desse modo, Derrida discute, a partir das reflexões de Kant e Austin, a responsabilidade constatativa das instituições como a competência científica que descreve a realidade na busca pela verdade.

A responsabilidade performativa, por sua vez, configura-se como uma competência técnica e se preocupa concomitantemente não só com o rendimento de um sistema técnico, mas também com o ato de linguagem, que "produz ou transforma, por si só, em certas condições, a situação de que fala" (DERRIDA, 1999, p. 105). Com o ato de linguagem, portanto, inviabiliza-se a delimitação entre o constatativo e o performativo, descontroem-se as fronteiras entre o pensar e o agir, 
pois o pensamento age e repensa o performativo, na medida em que responde às interlocuções e discursos e abre-se ao "porvir do acontecimento, ao que vem, ao que talvez venha de uma margem totalmente outra", de modo que se desloca o conceito do centro, a ilusão do controle que busca regular e manipular discursos, traduções, competências e desempenhos (DERRIDA, 1995, p. 125). Esse acolhimento do porvir se revela no discurso como sensibilidade singular, como razão interpretada, na qual "a razão é sensibilidade" que se desloca em um movimento de pensamento desconstrutor (DERRIDA, 2009, p. 45).

Em Farmácia de Platão, por exemplo, o sentido da escrita sofre uma proliferação de traduções. O Rei questiona a solução apresentada por Fedro, o intuito era que a escrita beneficiasse os indivíduos, na medida em que registrava os pensamentos, prevenindo-os do esquecimento, atuando como remédio para a memória. No entanto, o Rei provoca Fedro rasurando a interpretação do sentido da escrita, que também atuava como veneno para a memória, já que o indivíduo poderia acomodarse ao ponto de não desenvolver sua inteligência. Na medida em que tudo está escrito, por qual motivo iria se esforçar para lembrar os seus pensamentos? Assim, a posição do Rei exemplifica o logocentrismo, pois desqualifica a escrita, que só tem valor com a presença, com o discurso desenvolvido por meio da fala, nesse sentido, a escrita somente representa a fala. Essa discordância de interpretações entre o Rei e Fedro leva a entender a escrita como pharmakon, remédio e veneno ao mesmo tempo, de acordo com as singularidades do acontecimento e da situação vivida no evento (DERRIDA, 1997).

Jacques Derrida, portanto, não busca destruir o discurso, derrubar o centro da estrutura do texto, mas sim desestabilizar a base da metafísica ocidental, que se desenvolveu a partir de dicotomias, de pressupostos que valorizam a oposição de ideias. Assume-se, neste percurso de deslocamento, outra maneira de pensar, na qual a ausência de centro, de origem possibilita compreender tudo como discurso, que pode ser interpretado e lido de maneira diferente (NASCIMENTO, 2005). Essa desestabilização dos sentidos ocorre por meio da identificação das metáforas interpretativas que dão base para os discursos e práticas do processo de centralização. Questiona-se, desse modo, a possibilidade da tradução verdadeira, correta, e fiel ao dito "original", o que ocorre é a proliferação de sentidos, manifestada não por polissemia, mas por disseminação, com instabilidade, descentramento e traduções (DERRIDA, 1997). Neste processo de ler o texto em busca de suas metáforas e contradições, evidenciam-se os elementos dicotômicos que naturalizam a hierarquia e impedem as experiências de aporia, que são momentos de instabilidade nos 
discursos e práticas, na qual se vivencia a ausência de conceitos e caminhos de interpretação (DERRIDA, 2010).

Pode-se compreender, assim, que os discursos empresariais, a partir desta perspectiva, são permeados por estruturas políticas e institucionais, que se desenvolvem a partir de um centro, na busca pelo controle das interpretações e discursos dos atores organizacionais. Este controle é viabilizado pela aplicação de técnicas gerenciais (sistemas de regras e indicadores), inseridas dentro de um contexto marcado por metáforas que justificam a interpretação oficial e intervencionista de curto prazo em detrimento da reflexão teórica e profunda de longo prazo (BARBOSA, 2002). A análise derridiana deste processo possibilita desestabilizar as estruturas e discernir "no discurso" o que ainda não foi lido "na elaboração dos conceitos e funcionamento das instituições" (WOLFREYS, 2009, p. 59).

Assumindo esta postura na análise, pode-se perceber que o desenvolvimento dos discursos sobre sustentabilidade é marcado pela ambiguidade, principalmente no que se refere à relação da empresa com o meio ambiente. Nesse sentido, observa-se que o relatório Nosso Futuro em Comum (1987), facilitou a acolhida à questão socioambiental ao defender a integração de fatores econômicos, sociais e ambientais. Esta abertura provocou o setor a colocar em pauta temas que não estava acostumado a discutir, como por exemplo, alterações climáticas, questões sobre o uso sustentável da água, biodiversidade, ecossistema, entre outros. Cada segmento empresarial buscou se posicionar diante destes temas de maneira a responder às exigências econômicas de curto prazo e, ao mesmo tempo, lidar com a perspectiva ambiental de longo prazo. Assim, estes temas, inseridos no debate empresarial, causaram um estranhamento, um impasse na discussão, que pode ser compreendido como uma aporia, um momento de ausência de caminhos de interpretação.

Compreender essas aporias e ambiguidades na discussão da sustentabilidade empresarial é um dos propósitos desta pesquisa, que busca estudar as metáforas, sob a perspectiva derridiana, na qual a disseminação de sentidos e traduções é um aspecto que precisa ser considerado no percurso de significação. Reconhece-se, portanto, que o pensamento da desconstrução de Derrida, favorece a identificação de contradições e lacunas, de modo a criar alternativas de interpretação, que não reproduzem a simples oposição de ideias e a concepção de centro do discurso, com o intuito de desenvolver a leitura do texto a partir da margem, do que está à parte do logocentrismo. Neste jogo discursivo, surgem atores como os think tanks, que são compreendidos como entidades que se propõem a mediar a relação entre governos, 
empresas e sociedade, abrindo o debate de sustentabilidade empresarial à leitura de outros discursos, práticas e traduções.

Os think tanks atuam na assessoria política e econômica de governos e empresas, com intuito de influenciar discursos e práticas. O conceito think tank é derivado da organização RAND Corporation, que se constituiu em um espaço para o pensamento estratégico dos EUA após a Segunda Guerra. O WBCSD, objeto de estudo deste artigo, pode ser considerado um exemplo de think tank, na medida em que busca organizar espaços de debate como o Congresso Mundial de Conservação (CMI), que visa influenciar a agenda internacional da biodiversidade. Outras iniciativas que corroboram essa afirmação são as publicações de documentos que sintetizam o pensamento do WBCSD sobre temas como: biodiversidade, mudanças climáticas e desenvolvimento sustentável. Sendo assim, no que se refere à sustentabilidade, Vinha (2010) destaca a atuação das instituições internacionais e organizações multilaterais, como a Organização para Cooperação e Desenvolvimento Econômico (OCDE) e a Organização das Nações Unidas (ONU), na recomendação e cobrança para as empresas implantarem sistemas de gestão ambiental com o intuito de diminuir o impacto ambiental de seus negócios.

Como se pode observar, o papel de organismos internacionais e nacionais da Sociedade Civil é fundamental para a inserção da temática da sustentabilidade nos discursos e práticas das empresas. O surgimento de instituições think tanks é um dos sinais deste cenário, o objetivo dessas organizações é a realização e divulgação de estudos de modo a influenciar a agenda política e empresarial de diversas áreas, entre elas a discussão da sustentabilidade (STONE, 2015). A leitura derridiana da atuação dos think tanks, por sua vez, nos possibilita desconstruir os seus conceitos e metáforas, já que a interpretação de sua história revela ambiguidades sobre os discursos e o modo de agir dessas entidades.

Pode-se começar esta leitura pelo modo com que o termo think tank foi inicialmente traduzido para países como Portugal e Brasil. Estas organizações ficaram conhecidas como Usina de Ideias, por representarem espaços que se dedicavam a desenvolver e "fabricar" soluções, caracterizando-se como centros de referências, especialistas em um determinado tema. Além disso, o intuito desta associação com a indústria era obter o reconhecimento do mercado, de um espaço eficiente e eficaz no que se propõe a desenvolver. No entanto, ao relacionar think tank com o modo de funcionamento de uma fábrica, corre-se o risco de adotar uma abordagem que compreende a realidade a partir de uma lógica de causa e efeito, o que prejudica a análise de fenômenos complexos, como é o caso das discussões relacionadas ao DS. 
Por outro lado, os discursos dos think tanks podem possibilitar outras interpretações sobres os fenômenos complexos. Isso ocorre quando estas entidades realizam suas análises considerando os diversos discursos que se posicionam sobre o assunto em questão, neste percurso o intuito não é definir qual a posição mais coerente para se buscar determinado objetivo, seja de interesse de governos ou empresas, mas reconhecer quais são as diversas leituras e traduções de modo a compreender a complexidade da temática estudada. Assim os think tanks podem assumir posturas diferentes em sua atuação, abrindo os seus discursos e práticas a interpretações diversas ou buscando um discurso definitivo, impondo seu ponto de vista aos outros atores sociais com regras e estatutos. Desse modo, a análise derridiana nos possibilita desenvolver metáforas para compreender a tradução dos diversos temas, realizados por estas entidades. Pode-se, por exemplo, desconstruir o termo think tank desenvolvendo uma metáfora de leitura, a think tanke!
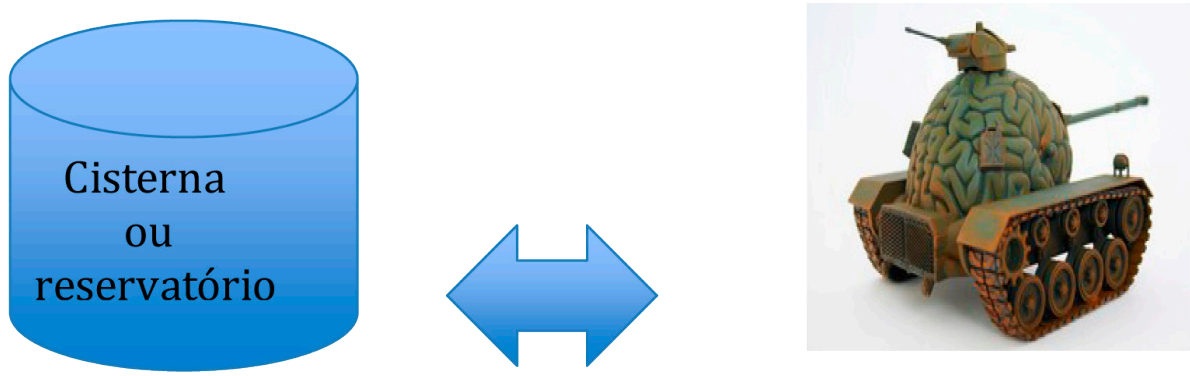

Figura 2. Metáfora think tanke.

Fonte: Autor a partir da discussão teórica, desenho inspirado na figura "tanque pensante" de Jason Freeny. ${ }^{1}$

A metáfora think tanke busca deslocar a hierarquia entre a escrita e a linguagem. Quando se insere "e" na palavra tank, a sua escrita sofre uma mudança, mas a pronúncia é pouco afetada, criando uma expressão que não existe em inglês, mas que aproxima o problema de sua interpretação à língua portuguesa. Em inglês tank pode significar cisterna, depósito, reservatório, piscina, mas também, em determinadas situações, pode significar carro blindado. Ou seja, ao criar a palavra "tanke" e associá-la à palavra think busca-se, por meio desta rasura na escrita e na linguagem, problematizar qual tipo de pensamento o WBCSD revela por meio de seus discursos. Um pensamento blindado, fechado a outras interpretações

1. Jason Freeny é um artista americano especializado em escultura.

Fonte: http://rockntech.com.br/think-tank-o-tanque-de-guerra-pensante 
e discursos (regras, requisitos, normas e estatutos), ou um pensamento cisterna, vinculado à ideia de piscina e reservatório, aberto a outras leituras e influências do tempo, que pode, de acordo com as alterações climáticas do ambiente, ser afetado pelas diversas rasuras e leituras, modificando este percurso de tradução.

Explica-se que a "cisterna" é uma tecnologia popular que se baseia nos princípios de sustentabilidade e é aplicada no Nordeste do Brasil por meio da captação de água nos períodos de chuva, a fim de que nos momentos de crise de abastecimento utilize-se o líquido reservado. Neste sentido, o pensamento cisterna representa os discursos do think tanke que se abrem à diversidade de opiniões e leituras, com o intuito de desenvolver estratégias para agir de um modo sustentável nos períodos de abundância e nas situações de crise.

Assim como o pharmakon é remédio e veneno ao mesmo tempo, a metáfora think tanke é um "pensamento cisterna $\leftrightarrow$ pensamento blindado" que se abre e que se fecha a outros discursos em um movimento de ambiguidade, contradição e indecidibilidade. No que diz respeito ao pensamento blindado, verifica-se o discurso associado ao tanque pensante, que considera a sustentabilidade na lógica da hospitalidade convite, com condições. Deste modo, a questão socioambiental é compreendida como algo relacionado ao ambiente externo da organização, que só pode avançar para o ambiente interno quando respeita os requisitos (normas e regras) previamente estabelecidos pela empresa. Assim, há uma visão que condiciona as iniciativas da empresa na área de sustentabilidade, colocando-se como verdade, como meta a ser alcançada por meio do desenvolvimento de programas e projetos, no qual o controle é realizado por meio de indicadores e ferramentas gerenciais.

Na perspectiva do pensamento cisterna, por sua vez, observa-se uma postura incondicional, ao considerar a imprevisibilidade dos acontecimentos da questão socioambiental. Neste sentido, compreende-se a discussão sobre desenvolvimento sustentável além da oposição entre responsabilidade empresarial (ambiente interno) e responsabilidade socioambiental (ambiente externo) ao ponto de observar traços e espectros que se abrem aos temas sustentáveis, como é o caso das alterações climáticas, que interferem no cotidiano dos negócios. Além disso, neste pensamento cisterna, a dicotomia entre visão (constatativa) e ação (performativa) é desconstruída, visto que se repensa o performativo que acolhe o porvir, sem requisitos, deslocando o discurso do think tank que busca influenciar e controlar interpretações.

Não se observa dicotomia na metáfora think tanke, o "pensamento cisterna $\leftrightarrow$ pensamento blindado" revela-se por meio da antinomia não dialetizável e da heterogeneidade dissimétrica, similar a discussão entre hospitalidade condicional e 
hospitalidade incondicional. Nesse sentido, a antinomia não dialetizável refere-se a impossibilidade de síntese e conciliação na metáfora think tanke. $\mathrm{O}$ pensamento cisterna, portanto, inscreve-se na lógica de controle do pensamento blindado sem perder a indissociabilidade da relação. A heterogeneidade dissimétrica, por sua vez, relaciona-se a hospitalidade incondicional do outro (questões socioambientais), que perverte as normas instituídas do pensamento blindado (estatutos e regras da empresa), abrindo a oportunidade para torná-las mais acolhedoras. Assim, o dissimétrico da relação é conservado, o que significa uma tensão indecidível no movimento de tradução, marcado pela contradição e ambiguidade (DERRIDA, 2003, p. 71).

Com essa leitura, observa-se que o pensamento cisterna necessita do pensamento blindado para tornar-se efetivo. Ainda que os requisitos, as determinações e o discurso definitivo que o tanque pensante busca impor pervertam a incondicionalidade que as questões socioambientais do pensamento cisterna exigem, essa perversibilidade é essencial, visto que no cotidiano há o evento da decisão, o instante em que se criam as condições para que o pensamento cisterna efetivese. No entanto, observa-se hierarquia entre estes dois termos (heterogeneidade dissimétrica), o pensamento cisterna está acima do pensamento blindado, ao assumir um ponto de vista crítico no que se refere às instituições (estatuto, regras e leis) e expor suas lacunas e limitações. Neste sentido, a cada passagem do pensamento cisterna nos requisitos e normas estabelecidas pelo tanque pensante, abre-se uma aporia nas regras instituídas, uma brecha que possibilita meios para torná-las mais justas e acolhedoras às questões socioambientais. Ainda que o pensamento cisterna se inscreva nas normas do pensamento blindado, conserva-se um perfil de contraditoriedade, antinomia e indissociabilidade nessa relação. Isso significa que think tanke não é uma sintagma que possui vários significados (BERNARDO, 2001), mas sim um movimento de tradução, sincategorema, um quase conceito, um conceito incompleto, metáfora de leitura do percurso de significação sobre a sustentabilidade empresarial (BERNARDO, 2007). Desta feita, assume-se a metáfora think tanke como modo de traduzir a relação das empresas com a questão socioambiental, atento aos desvios do caminho discursivo.

\section{PERCURSO METODOLÓGICO}

A decisão pela desconstrução de Derrida enquanto percurso analítico envolve uma postura metodológica que compreende os discursos do WBCSD como espaço de traduções e ambiguidades (COOPER \& BURREL, 1988). Desconstrução "é 
um modo de tomar posição, em seus trabalhos de análise, no que diz respeito às estruturas políticas e institucionais que constituem e regulam nossas práticas, nossas competências e nossos desempenhos" (DERRIDA, 1999, p.108). Neste sentido, resiste-se à ideia de caminho pré-estabelecido, desloca-se os discursos que disseminam os pensamentos logocêntricos e assume-se o jogo do rastro ao ler a metáfora como língua em viagem (DERRIDA, 1995, p. 125). Nesta pesquisa isso significa estudar as narrativas e documentos do WBCSD de modo a identificar as estruturas políticas e institucionais que servem de referência para os discursos desenvolvidos pela entidade. Assim, a desconstrução permite observar a tônica logocêntrica ou não das metáforas, isto é, se há acolhida a diversas interpretações e traduções sobre sustentabilidade no ambiente empresarial.

Com este propósito, acompanharam-se os discursos de dois conselhos, Brasileiro e Português. Procedeu-se uma série de visitas in loco nestas instituições, Brasileira e Portuguesa, e conduziu-se um conjunto de entrevistas em profundidade. Foram entrevistados três integrantes da Equipe de Gestão do BCSD Portugal, denominados nesta pesquisa como Coordenação P. No BCSD Brasil foram entrevistados três integrantes da Equipe de Gestão, denominados como Coordenação B. Além disso, foram entrevistados seis especialistas em desenvolvimento sustentável. Eles buscaram analisar as estruturas políticas e institucionais que facilitam e dificultam a acolhida das questões socioambientais nas empresas. O caminho analítico da pesquisa considerou os quase conceitos do percurso de desconstrução de Derrida ao analisar as críticas que o autor apresenta ao logocentrismo e às questões direcionadas ao desenvolvimento de metáforas e traduções (DERRIDA, 1973). São estes os elementos-chave que nortearam a análise dos discursos do WBCSD. Eles foram agrupados em três categorias.

\section{Quadro 1. Categorias de análise}

\begin{tabular}{|l|l|l|}
\hline \multicolumn{2}{|c|}{ Descrição segundo Derrida } & \multicolumn{1}{|c|}{ Como foi lido na pesquisa? } \\
\hline Pensamento confiante na & Entende- se que o WBCSD é um tbink \\
centralidade e no poder do & tank que busca influenciar empresários \\
logos desenvolvido com base em & por meio de seus discursos sobre \\
oposições e dicotomias, na qual & sustentabilidade. O WBCSD, portanto, \\
se cria relações hierárquicas entre & é um centro produtor de metáforas, que \\
tegocentrismos, servindo de referência para & serve de referência para interpretações e \\
interpretações e traduções, com o & traduções. Nesta pesquisa, procurou-se \\
intuito de controlar e centralizar os os & estudar o WBCSD de modo a identificar \\
discursos (DERRIDA, 1973) & as contradições e ambiguidades de seu \\
\hline
\end{tabular}




\begin{tabular}{|c|c|c|}
\hline Metáfora & $\begin{array}{l}\text { Em Derrida, metáfora não pode ser } \\
\text { compreendida como analogia de } \\
\text { coisas distintas, mas sim como um } \\
\text { movimento para compreender o } \\
\text { discurso, meio de inventar palavras } \\
\text { para deslocar interpretações e abrir } \\
\text { espaço para outras traduções, em } \\
\text { que a analogia e a oposição são } \\
\text { desviadas e se desfazem. }\end{array}$ & $\begin{array}{l}\text { Nesta pesquisa desenvolveu-se a metáfora } \\
\text { think tanke, que apresenta a antinomia não } \\
\text { dialetizável pensamento cisterna } \leftrightarrow \rightarrow \\
\text { pensamento blindado. O pensamento } \\
\text { cisterna é lido a partir da hospitalidade } \\
\text { incondicional, aberto à visita e imprevistos } \\
\text { da questão socioambiental. O pensamento } \\
\text { blindado, por sua vez, traduz-se por meio } \\
\text { da hospitalidade condicional e estabelece } \\
\text { regras, normas e requisitos para acolher a } \\
\text { discussão do desenvolvimento sustentável. }\end{array}$ \\
\hline Tradução & $\begin{array}{l}\text { A tradução é um outro nome } \\
\text { para desconstrução, sendo um } \\
\text { exemplo da abertura ao outro } \\
\text { (BERNARDO, 2001). É um gesto } \\
\text { passível de ilustrar uma experiência } \\
\text { de leitura e de interpretação } \\
\text { marcada por desvios re-inventivos } \\
\text { de sentidos, descentramentos e } \\
\text { rastros. (FERREIRA; OTTONI, } \\
\text { 2006, p. 32). }\end{array}$ & $\begin{array}{l}\text { A tradução implica atentar e estudar como } \\
\text { a empresa acolhe a discussão da questão } \\
\text { socioambiental. Sob uma lógica convite, } \\
\text { com condições, ou sob uma lógica visita, } \\
\text { de modo incondicional, por meio de uma } \\
\text { alteridade absoluta. Esse percurso de } \\
\text { tradução será lido nesta pesquisa por meio } \\
\text { da metáfora think tanke. }\end{array}$ \\
\hline
\end{tabular}

Fonte: Autores a partir da discussão de Derrida.

Com estas categorias em foco buscou-se compreender quais as contradições e ambiguidades que se revelam nas narrativas do BCSD Portugal e do BCSD Brasil. Neste trajeto, os estatutos, as regras e as ferramentas que buscam controlar as traduções foram lidos a partir da metáfora think tanke. Ou seja, o intuito não é destruir os estatutos que organizam a hospitalidade condicional, mas deslocar a dicotomia que estrutura o processo de significação. Todo este percurso analítico possibilitou observar se os discursos sobre desenvolvimento sustentável do WBCSD facilitam ou não a acolhida dos empresários à questão socioambiental.

\section{DISCURSOS SOBRE DS QUE PROMOVE ACOLHIDA E RESISTÊNCIA À QUESTÃO SOCIOAMBIENTAL NAS EMPRESAS}

No percurso da pesquisa foram identificados discursos que trabalham com o propósito de traduzir para o setor empresarial as questões socioambientais que envolvem o desenvolvimento sustentável. Com este foco foram desenvolvidas metáforas para justificar o uso de ferramentas de gestão que se propõe a medir a relação de dependência dos negócios com os recursos socioambientais. No entanto, neste estudo, a criação de metáforas é problematizada, mais do que um elemento 
neutro ou instrumental de comunicação, reconhece-se um jogo de linguagens no qual as diferenças se relacionam por meio do pensamento da alteridade. Assim, os discursos foram lidos de modo a perceber como a metáfora da língua em viagem desconstruiu o modelo prévio estabelecido pela metáfora Empresa Sustentável cuja estrutura é explicada a seguir.

Quadro 2. Discursos das coordenações do WBCSD sobre DS.

\begin{tabular}{|l|l|l|}
\hline $\begin{array}{l}\text { 1- Você não pode gerir o } \\
\text { que você não pode mensurar } \\
\text { (Coordenação P2) }\end{array}$ & $\begin{array}{l}\text { 2- Uma vez mensurado você } \\
\text { pode fazer o gerenciamento. } \\
\text { (Coordenação P1) }\end{array}$ & $\begin{array}{l}\text { 3- Os empresários são os } \\
\text { atores da sociedade com maior } \\
\text { capacidade para liderar o } \\
\text { processo de desenvolvimento } \\
\text { sustentável (Coordenação P3). }\end{array}$ \\
\hline $\begin{array}{l}\text { 4- Se a alta liderança CEO } \\
\text { não concordar com o projeto } \\
\text { a coisa não caminha. Nós } \\
\text { precisamos sensibilizar a alta } \\
\text { liderança. } \\
\text { (Coordenação B2) }\end{array}$ & $\begin{array}{l}\text { 5- Queremos ser a vanguarda } \\
\text { da sustentabilidade } \\
\text { empresarial (Coordenação } \\
\text { B1) }\end{array}$ & $\begin{array}{l}\text { 6- É preciso dar velocidade } \\
\text { e escala pra ser ouvido } \\
\text { (Coordenação B3) }\end{array}$ \\
\hline
\end{tabular}

Fonte: Autor a partir da análise de dados.

Os discursos revelam o argumento de que há Empresas Sustentáveis, que conseguem medir a sua dependência com relação aos recursos socioambientais, e Empresas não Sustentáveis, que não conseguem desenvolver um sistema de gestão sustentável. Defende-se um modelo de gerenciamento vinculado ao pensamento blindado e à hospitalidade condicional cuja lógica é centrada no uso de ferramentas e indicadores. O que se percebe, portanto, é a criação da metáfora da Empresa Sustentável com base em oposições, ferramentas de gestão e discursos que legitimam critérios para lidar com as questões socioambientais (TATIM, GUARESCHI, 2012; GITSHAM, 2012).

A trajetória de pesquisa revelou um pensamento confiante na centralidade e no poder do logos que se viabiliza pela relação hierárquica entre os termos sustentável e não sustentável, servindo de referência para interpretações e traduções para o setor empresarial, com o intuito de controlar os discursos. Defende-se que os empresários são os atores com maior capacidade de liderar o processo de desenvolvimento sustentável por possuírem mais dinheiro do que as ONGs e mais "flexibilidade em suas ações do que os governos" (Coordenação P3). Assim, segundo o WBCSD, a acolhida das questões socioambientais pressupõe o investimento em capacitações para que as lideranças empresariais compreendam a sua função neste processo, conforme se evidencia na seguinte afirmação: 
À medida que o empresário compreende a importância de liderar o processo de DS, ele começa a buscar ferramentas que o auxiliem na tarefa de gerenciar a questão socioambiental. (Coordenação P3).

No entanto, um dos desvios deste percurso de significação é a leitura das lideranças sobre a relação das empresas com o meio ambiente, que tende a ser ambígua e contraditória. Isso ocorre quando se limita a discussão da questão socioambiental à dependência de recursos naturais e os impactos ambientais dos negócios, sem considerar fatores não controláveis como, por exemplo, as alterações climáticas. Esses fatores ingovernáveis são questões socioambientais que não se reconhecem na ordem do calculável e da regra e provocam o "ser finito" a tomar decisões e lidar com a "hos-ti-pi-talidade" e as ambiguidades. Ainda que a hospitalidade incondicional (questão socioambiental) se inscreva nas regras da hospitalidade condicional (estatutos empresariais), verifica-se a preservação da contraditoriedade, antinomia e indissociabilidade na relação, com a hospitalidade incondicional assumindo um papel crítico frente às normas e regras instituídas, buscando torná-las mais acolhedoras (BERNARDO, 2005, p. 190).

Verifica-se também impasses no que tange a criação de ambientes favoráveis aos negócios sustentáveis. A Coordenação B1 argumenta que os governos precisam criar um ambiente propício para que os empresários liderem o processo de DS, já que "não adianta a empresa adotar uma produção sustentável se o ambiente propiciado pelo governo favorece o uso de energia que consome combustíveis fósseis e não energias renováveis". Assim se, por um lado, os empresários questionam a intervenção do Estado na economia, exige-se, por outro lado, políticas públicas e legislações que criem condições para a gestão sustentável. O governo é reconhecido, ambiguamente, como instância soberana, com poder para definir o ambiente propício para o desenvolvimento de negócios sustentáveis. Ignora-se, com essa postura, as estruturas políticas e institucionais que interferem no instante da decisão, e impedem o controle das interpretações.

As traduções do WBCSD para o ambiente corporativo, por sua vez, visam sistematizar as experiências e metáforas no campo da gestão sustentável. A entidade busca divulgar essas informações por meio de duas estratégias, o desenvolvimento de guias de sustentabilidade e a realização de espaços de discussão para sensibilizar, envolver e engajar o empresário no processo de DS. Há interesse em instrumentalizar e influenciar as interpretações e traduções do empresário sobre as questões socioambientais que afetam o seu negócio. Ciente deste propósito, ao se analisar os discursos das coordenações do WBCSD, à luz da metáfora think tanke, verificase que a acolhida do DS nas empresas está associada a uma série de critérios que 
precisam ser atendidos. Espera-se que as empresas consolidem regras, ferramentas e procedimentos (práticas de gestão) para incluir as questões socioambientais em seu planejamento estratégico. Deste modo, a discussão de desenvolvimento sustentável e das políticas públicas do governo é compreendida pelas empresas como fatores externos ao negócio. Ou seja, as questões socioambientais (ambiente externo) só são acolhidas pela empresa (ambiente interno) quando respeitam os requisitos estabelecidos pelos gestores.

É neste cenário que se reconhece as ambiguidades dos discursos do WBCSD sobre DS. Na busca por traduzir para as empresas as questões socioambientais que envolvem os objetivos do DS, a entidade tende a focar na definição de critérios, condições e ferramentas de gestão, tal postura alinha-se à discussão da hospitalidade condicional e pensamento blindado. Concomitantemente, estes discursos atuam de maneira crítica exigindo que as práticas das empresas estejam de acordo com critérios para serem reconhecidas como Empresas Sustentáveis. Nesta situação específica, verifica-se que os discursos do WBCSD possuem potencial para tornar as empresas mais acolhedoras à discussão de sustentabilidade empresarial. Deste modo, quando se propõe a metáfora think tanke para traduzir a relação das empresas com o DS, não se procura limitar-se a denunciar as falhas deste processo, mas sim reconhecer, nas insuficiências das regras instituídas, oportunidades para repensá-las e torná-las mais justas e acolhedoras. É neste ponto que se evidencia a diferença entre a metáfora da Empresa Sustentável e a metáfora think tanke. Na metáfora da Empresa Sustentável o intuito é assimilar e integrar, reduzir as múltiplas traduções sobre sustentabilidade. Na metáfora think tanke, por sua vez, se revela uma língua em viagem, um quase conceito, um conceito aberto ou incompleto que problematiza as contradições e ambiguidades do discurso do WBCSD e acolhe as diversas traduções sobre DS.

\section{A VISÃO DOS ESPECIALISTAS}

Segundo os especialistas entrevistados, o caminho para aprofundar as mudanças nas estruturas políticas e institucionais envolve a alteração do estatuto e dos valores, com a criação de metáforas que reconheçam a metáfora como língua em viagem na tradução do desenvolvimento sustentável para o ambiente corporativo. Destaca-se que, neste artigo, a leitura da língua se da a partir da lei da ex-apropriação, como prótese de origem, como apropriação interminável de um não próprio irredutível (ARAÚJO, 2015, p. 95). A metáfora como língua em viagem desconstrói a ideia de que há um modelo prévio a seguir com a interdição 
da propriedade. Há uma dissimetria absoluta da relação com a originalidade, com o próprio sendo metaforizado, deslocado e ex-apropriado (BERNARDO, 2007). Há o luto da presença, o luto da razão, o luto do sujeito e o luto de qualquer instituição soberana. (DERRIDA, 2013, p. 105). O intuito dessa leitura é o deslocamento do percurso de significação com o acolhimento incondicional dos diversos discursos sobre desenvolvimento sustentável.

O que acontece com as iniciativas de sustentabilidade? Eu realizo trabalho com os stakeholders, internos e externos, altero a missão, crio um documento e ponho no website com muitos gráficos. O que propomos para ir além desta limitação é a alteração do estatuto da empresa com a exposição clara de que a instituição será gerida por determinado tipo de valores e indicadores, deste modo eu estabeleço um conjunto de indicadores de gestão para os Administradores, de modo que estes não se limitem ao lucro trimestral, mas que considerem o ponto de vista da sustentabilidade e da responsabilidade social (Especialista P1).

Ao analisar o caso do BCSD Portugal, observou-se que o Conselho Empresarial procurou expandir sua área de influência por meio da participação em espaços como a Rede Nacional de Responsabilidade Social - RSOL. O propósito da Rede é discutir caminhos para facilitar a tradução do desenvolvimento sustentável nas empresas. No entanto, há limites que impedem o aprofundamento dessa discussão no cotidiano dos negócios. Um destes limites, por exemplo, são os estatutos e normas que, apesar de incorporarem discursos de sustentabilidade, não consideram questões de natureza ideológica e de poder (SPRINGETT, 2003). A resistência à regulação do mercado revela uma postura ideológica do empresário que dificulta a discussão das questões socioambientais.

Não entendo a resistência dos empresários à regulação, acredito ser muito mais uma questão ideológica, pois se eu olhar para o benefício de minha empresa eu vou ver que tenho muito mais a ganhar com regras transparentes e claras em que todos os atores têm que jogar com elas, do que permitir que os espertos ganhem dinheiro no mercado. Ou seja, é necessário discutir e encontrar o contraponto entre autorregulação e regulação do Estado (Especialista P2).

A regulação do Estado na economia não é algo ruim para os empresários e para a sustentabilidade, desde que as limitações e as consequências desta ação sejam discutidas com os setores afetados por tais medidas (Especialista B3).

Há diversas formas de relações com "o governo, a universidade, a identidade nacional, o conceito de dom ou a ideia de enlutamento", (WOLFREYS, 2009, p. 51). Essas relações foram analisadas por meio de seus espectros e alteridades, compreendidos como experiências da desconstrução da presença (DERRIDA, 2013, p. 105). Deste modo, a resistência do empresário em discutir aspectos da regulação do Estado na economia, que favoreça o DS, acaba por dificultar o diálogo com o 
governo, o que revela uma situação de conflito de interesses (STAHEL, 1994). Assim, ao ler este cenário a luz da metáfora think tanke, observa-se um problema de hospitalidade dos empresários com as legislações socioambientais, principalmente com aquelas que interferem nos processos de negócios. O Especialista P3 nos ajuda a compreender esse conflito de poderes, ao apresentar sua análise sobre a atuação do BCSD Portugal e do BCSD Brasil, e destacar a necessidade de se dialogar com os sharebolders.

No fundo a própria concepção em torno das práticas de sustentabilidade foram colocadas em questão pois elas foram montadas para uma empresa que não existe. Um cenário cujos chefes trabalham e vivem na empresa, quando na verdade, cada vez mais, os acionistas são terceiros investidores, ou são instituições ou são fundos, ou seja, há estratificação dos shareholders. Assim, não estamos dialogando com quem manda na empresa, com os acionistas que tomam decisões voltadas para o curto prazo. (Especialista P3)

Com a consolidação deste modelo de organização mais fragmentado, defendese o desenvolvimento de novas ferramentas para dialogar com os disseminadores de discursos logocêntricos (shareholders), de modo a promover alterações nos processos de tradução. Observa-se que a metáfora da Empresa Sustentável, serve de referência para esse discurso, já que se acredita na possibilidade de mudanças das estruturas políticas e institucionais a partir da aplicação de determinados procedimentos, ferramentas e indicadores. Neste sentido, os especialistas ouvidos apoiam a criação de mecanismos legais que obriguem as empresas a considerar em seus preços, externalidades que afetam os seus custos, de modo a valorizar aquelas que acolhem a questão socioambiental em suas práticas de sustentabilidade.

Quando a empresa olha para o mercado e diz "Nós temos que baixar os custos da fatura energética, nós temos que produzir um tipo de produção agrícola que seja menos intensiva do ponto de vista da utilização de solos, da água e energia", ela favorece o DS. No entanto, isso funciona em certos nichos de mercado e em momentos de expansão econômica em que há investimento por parte da política pública para que isso funcione, mas quando há menor capacidade de investimento do setor privado ou do Estado isso não ocorre, ou seja, o impacto é de curto prazo (Especialista B1).

Os discursos de sustentabilidade empresarial respondem a um paradigma econômico que ignora questões sociais e ambientais. Isto se evidencia no discurso dos negócios, na medida em que não se discutem fatores como exploração do trabalho e de recursos. Há, portanto, um conflito de poder para definir o conceito de DS e seus desdobramentos com disputas marcadas por controles ideológicos e políticos (SPRINGETT, 2003). Percebe-se que os investimentos corporativos na questão socioambiental alinham-se à discussão de hospitalidade condicional e pensamento blindado quando pressupõem um cenário com expansão econômica 
e com alta capacidade de investimento do poder público. Na ausência desses requisitos, como no caso de crises econômicas, a tendência é que a realização de políticas sustentáveis seja interrompida. Um modo de problematizar esta interrupção é repensar a relação do meio ambiente com a economia, levando em consideração a dependência da natureza, que disponibiliza insumos para a indústria, por exemplo, (BALDISSERA; KAUFMANN, 2013).

Se eu não tenho nenhum mecanismo legal que me obrigue a incorporar aquilo que são as prerrogativas, externalidades negativas ou positivas no preço do meu produto, o preço nunca irá refletir o que é o custo de fato. Nós temos uma série de preços que não revelam o custo de produção, pois só consideram o trabalho e a matéria-prima em sua análise, ignorando aspectos relacionados à questão ambiental e social (Especialista B2).

Outro aspecto que precisa ser aperfeiçoado nas estruturas políticas e institucionais é a alteridade com o porvir, que se revela, por exemplo, na adoção de tecnologias mais sustentáveis no processo de produção. A adoção dessas inovações nem sempre ocorrem de modo incondicional, sendo adotada, muitas vezes, pela via da regulação (legislação ambiental). Neste sentido, para que a relação das empresas com a questão socioambiental seja algo consistente e de longo prazo, defende-se a promoção de diálogos entre mecanismo de mercado e regulação. Este diálogo precisa considerar a antinomia não dialetizável e a heterogeneidade dissimétrica da relação entre pensamento cisterna e pensamento blindado. Isso significa que o pensamento cisterna necessita inscrever-se na lógica do pensamento blindado para tornar-se efetiva, não utópica e não abstrata (DERRIDA, 2003, p. 71). Neste percurso, o pensamento blindado da questão socioambiental (instituído) é pervertido pelo pensamento cisterna (hospitalidade incondicional), ao reconhecer as insuficiências das regras e estatutos na busca pela justa acolhida do DS.

Não basta que o WBCSD restrinja sua atuação à divulgação das iniciativas de Empresas Associadas. É preciso que os Conselhos Empresariais sejam protagonistas e estimulem as empresas a desenvolverem ações de longo prazo, abdicando de determinadas tecnologias e substituindo por outras mais sustentáveis, quando necessário (Especialista B3).

Para garantir que as empresas invistam no meio ambiente e que isto tenha um retorno social, há de se ter um conjunto, por um lado de regulação, por outro lado de mecanismo de mercado, de mudança na maneira de perceber a própria empresa e sua atuação junto à comunidade local, a fim de que isto se torne, de fato, um movimento consistente e de grande impacto (Especialista P1).

Assim, para que o WBCSD consiga provocar alterações no estatuto das empresas, a análise da visão dos especialistas revela que a entidade necessita reconhecer a importância da hospitalidade incondicional e do pensamento cisterna 
no processo de tradução. Isso significa valorizar a escuta dos diversos discursos nos espaços de diálogo com o governo e com os movimentos socioambientais (Conselhos Nacionais de Políticas Públicas). Essa escuta precisa ocorrer de modo incondicional, acolhendo as imprevisibilidades da questão socioambiental, que se revelam no percurso de significação. Ou seja, além de promover diálogo entre os atores envolvidos, defende-se a importância de criar mecanismos legais que valorizem as empresas que se propõem a discutir questões de natureza ideológica e de poder. Isso se verifica quando a empresa reconhece no discurso de DS o outro absoluto. Revela-se um pensamento de alteridade que se traduz na desconstrução da relação entre hóspede (questão socioambiental) e hospedeiro (empresa). Essa relação lida por meio da metáfora think tanke, como língua em viagem, torna o hospedeiro refém das imprevisibilidades do hóspede (alterações climáticas, disponibilidade de água, biodiversidade etc), já que o "hospedeiro torna-se hóspede do hóspede" (DERRIDA, 2003, p. 109).

\section{DISCUSSÃO-METÁFORA EM VIAGEM NA TRADUÇÃO DO DESENVOLVIMENTO SUSTENTÁVEL PARA EMPRESÁRIOS DO BRASIL E DE PORTUGAL}

O que se observa ao analisar os discursos de um organismo empresarial, de alcance mundial, que promove ações educacionais de tradução para o ambiente corporativo do pensamento do desenvolvimento sustentável (DS)? Esses discursos sinalizam uma ação de disseminação do DS pela via da educação, que a priori entendese, como aquela que é capaz de provocar mudanças nos processos de significação ao considerar as diversas interpretações sobre a sustentabilidade. A base da sua ação, a tradução, é promissora, uma vez que a acolhida dos princípios do DS nas organizações pressupõe repensar os seus discursos e estatutos (SPRINGETT, 2003).

A estratégia para promover a acolhida da questão socioambiental foi a criação da metáfora Empresa Sustentável. Essa metáfora busca assimilar e integrar os diversos discursos sobre DS por meio de determinados procedimentos, ferramentas, discursos e indicadores. O que se verifica, entretanto, é que essa metáfora se constitui em um caminho pré-estabelecido, um círculo logocêntrico que se desenvolve com base na oposição do próprio e do não próprio. O próprio (ambiente interno da empresa) são as práticas de gestão, as ferramentas e indicadores utilizados para mensurar o resultado financeiro da empresa, os critérios definidos para gerenciar o negócio; o não próprio (ambiente externo), por sua vez, é a questão socioambiental que precisa respeitar os requisitos institucionais para ser assimilada e integrada ao 
discurso de sustentabilidade empresarial, dentro de uma lógica de hospitalidade condicional.

O exercício da Desconstrução do discurso permitiu observar a ambiguidade que se estabeleceu neste cenário (Derrida, 2001). A tentativa de incentivar novos temas e objetivos que rompem com a lógica insustentável convive com a necessidade de exercer controle, definindo os conteúdos e objetivos da formação empresarial neste processo. Esse impasse, no entanto, apresentou-se como brecha, como oportunidade de desconstruir a metáfora Empresa Sustentável (modelo prévio) e de repensar a relação da empresa com a questão socioambiental a partir da metáfora think tanke, como língua em viagem.

Neste sentido, os discursos sobre DS do WBCSD foram lidos por meio da antinomia não dialetizável e da heterogeneidade dissimétrica da relação entre pensamento cisterna e pensamento blindado. $O$ pensamento blindado da questão socioambiental é pervertido, guiado e inspirado pelo pensamento cisterna, assumindo suas insuficiências na busca pela justa acolhida. Isso significa que o pensamento cisterna (hospitalidade incondicional) necessita inscrever-se na lógica do controle para tornar-se efetiva, não utópica e não abstrata. Deste modo, quando se propõe a metáfora think tanke para traduzir a relação das empresas com o DS, não se procura limitar-se a denunciar as falhas deste processo, mas sim reconhecer nas insuficiências das regras instituídas oportunidades para repensá-las e torná-las mais justas e acolhedoras. Assim, a metáfora think tanke, compreendida como língua em viagem, assume a desconstrução como atitude de singular vigília em relação as estruturas políticas e institucionais, abrindo-as ao pensamento da alteridade, ao discurso que se desenvolve nessa experiência de significação (BERNARDO, 2007).

\section{CONCLUSÃO: AS METÁFORAS E AMBIGUIDADES DO DISCURSO DO WBCSD SOBRE DESENVOLVIMENTO SUSTENTÁVEL FACILITAM A ACOLHIDA DOS EMPRESÁRIOS À QUESTÃO SOCIOAMBIENTAL?}

O percurso de significação do WBCSD tem de ser constantemente questionado, revisitado e desconstruído para promover, de fato, alguma mudança nas estruturas e, à luz da metáfora think tanke, acolher as diversas traduções sobre sustentabilidade corporativa que podem ser assumidos nas experiências de aprendizagem promovidas pela entidade. Nesse sentido, buscou-se estudar as estruturas políticas e institucionais que facilitam e dificultam a acolhida da questão socioambiental nas empresas. Dedicou-se atenção às ambiguidades dos discursos dos empresários e às diversas formas e relações estabelecidas com "o governo, a 
universidade, a identidade nacional, o conceito de dom ou a ideia de enlutamento", (WOLFREYS, 2009, p. 51). Essas relações foram analisadas por meio de seus espectros, de seus traços e rastros, de seus lutos e alteridades, compreendidos aqui como experiências da desconstrução da presença (DERRIDA, 2013, p. 105).

Há necessidade do WBCSD lidar com as contradições e ambiguidades do discurso empresarial e repensar estratégias para promover estruturas políticas e institucionais (estatutos, regras e ferramentas de gestão) acolhedoras as discussões que envolvem o DS. Se por um lado o setor empresarial reconhece a imprevisibilidade das questões socioambientais nos discursos para os seus stakeholders (partes interessadas no negócio) e nas publicações de seu planejamento estratégico por outro lado verificam-se resistências em promover alterações no estatuto da empresa, com o desenvolvimento de indicadores e valores que não se limitem ao lucro trimestral, mas que considerem o ponto de vista da sustentabilidade e da responsabilidade social. Desse modo, ao ler este cenário à luz da metáfora think tanke, identificou-se um problema de hospitalidade dos empresários com as questões socioambientais que envolvem o DS, principalmente quando referem-se a problemas de natureza ideológica e de poder (conflituosas e incontroláveis). Assim, os empresários acolhem a discussão de DS sob a "lógica do convite" e lidam com dificuldade e resistência com as questões socioambientais imprevisíveis, que se apresentam sob a "lógica da visita", como é o caso das alterações climáticas, disponibilidade de água, biodiversidade, mudanças no ecossistema, entre outros.

Os discursos do WBCSD levam as empresas a repensar seus estatutos, ao reivindicar o respeito a critérios internacionais de sustentabilidade empresarial, traduzidos pela metáfora da Empresa Sustentável. No entanto esse discurso é insuficiente para acolher as diversas interpretações sobre DS já que o intuito é assimilar e integrar. A leitura dos discursos do WBCSD como língua em viagem, por sua vez, facilita a acolhida da questão socioambiental ao assumir o DS como quase conceito, um conceito incompleto ou aberto à participação dos empresários no percurso de significação. O WBCSD, portanto, colabora com a interrupção da metáfora da Empresa Sustentável, quando acolhe as várias leituras e relações que permeiam o processo de aprendizagem. Essa acolhida incondicional se torna possível por meio da desconstrução da relação entre hóspede (questão socioambiental) e hospedeiro (empresa). O que leva o hospedeiro a se tornar refém do hóspede, tornando-se "hóspede do hóspede" (DERRIDA, 2003, p. 109).

Neste sentido, como indicação de oportunidade para aprofundamento da pesquisa com estudos futuros, sugere-se que se busque analisar as iniciativas promovidas pelo WBCSD em outros países, visto que esta pesquisa concentrou-se 
nas experiências dos Conselhos Empresariais do Brasil e de Portugal. Este estudo ouviu Coordenadores e Especialistas que revelaram suas reflexões sobre os discursos e ambiguidades do WBCSD. Acredita-se que entrevistas com representantes de outras entidades favoreçam a acolhida de mais perspectivas sobre o desenvolvimento sustentável. Há outros think tanks (Foundation for Economic Education, Tinker Foundatioun) atuantes na área de sustentabilidade empresarial que podem ser investigados, com o intuito de compreender as traduções desenvolvidas. Propõe-se também, que a pesquisa dessas outras iniciativas ocorra sob o olhar da desconstrução e da metáfora think tanke, como língua em viagem, com atitude crítica em relação às estruturas que viabilizam metáforas logocêntricas e dificultam a acolhida das questões socioambientais nas empresas.

\section{$\overline{\text { REFERÊNCIAS }}$}

ARAÚ́JO, N. (2015). Teorizar em "Português Brasileiro"? ALEA. v.17, nº 1, pp. 92-113.

BARBOSA, L. (2002). Cultura de Negócios: Ambiguidades e Contradições. RAE, v. 42, $\mathrm{n}^{\mathrm{o}} 4$, pp. 106-109.

BALDISSERA, R.; KAUFMANN, C. (2013). Comunicação Organizacional e Sustentabilidade: Sobre o Modelo Instituído no Âmbito da Organização Comunicada. ORGANICOM. v.10, nº 18, pp.59-70.

BERNARDO, F. (2001) A ética da hospitalidade ou o porvir do cosmopolitismo por vir. Revista Filosófica de Coimbra, nº 20, pp. 333-426.

BERNARDO, F. (2007) "Metáfora" ou a língua em-viagem, pensar a metáfora no rastro de Derrida. Trabalhos em Linguística Aplicada, Edição Especial, pp. 137-170.

BERNARDO, F. (2005) Mal de hospitalidade. In: NASCIMENTO, E., Jacques Derrida: pensar a desconstrução. São Paulo: Editora Estação Liberdade.

COOPER, R; BURRELL, B. (1988). Modernism, postmodernism and organizational analysis: An Introduction. Organization Studies, v.9, n 1, pp. 91-112.

CULLER, J. Sobre a Desconstrução: teoria e crítica do pós-estruturalismo. Tradução de Patricia Cecilia Burrowes. Rio de Janeiro: Record Rosa dos Tempos, 1997.

DERRIDA, J. (2004). Adeus a Emanuel Lévinas. Tradução de Fábio Landa, Eva Landa. São Paulo: Perspectiva, 2013. 
DERRIDA, J. (1997). Anne Dufourmantelle convida Jacques Derrida a falar Da Hospitalidade. Trad. Antônio Romane. São Paulo: Escuta, 2003.

DERRIDA, J. (1972). La diseminación. Traducción de José Martín Arancibia. Caracas: Espiral, 1997.

DERRIDA, J. (1972). Margens da filosofia. Tradução de Joaquim Torres Costa e António M. Magalhães. Porto: Rés Editora, 1986.

DERRIDA, J. (1990). O Olbo da universidade. Tradução de Ricardo luri Canko e Ignacio Antonio Neis. São Paulo: Estação Liberdade, 1999.

DERRIDA, J. (2001).Universidade sem condição. Tradução de Evando Nascimento São Paulo: Estação Liberdade, 2003.

DERRIDA, J.(1967). Escritura e a diferença. Tradução de Maria Beatriz Marques Nizza da Silva. São Paulo: Perspectiva, 2002.

DERRIDA, J. (1994). Força de lei: o fundamento místico da autoridade. Tradução de Leyla Perrone-Moisés. São Paulo: Martins Fontes, 2010.

DERRIDA, J. (1967). Gramatologia. Tradução de Miriam Schnaiderman e Renato Janine. São Paulo: Perspectiva, 1973.

DERRIDA, J. (1990). O outro cabo. Tradução de Fernanda Bernardo. Coimbra: Ed. Universidade de Coimbra, 1995.

DERRIDA, J. (2001). Papel-Máquina. Tradução de Evando Nascimento São Paulo: Estação Liberdade, 2004.

DERRIDA, J. (1972). Posições: Entrevista com Jacques Derrida. Tradução de Tomaz Tadeu da Silva. Belo Horizonte: Autêntica, 2001.

DERRIDA, J. (2003). Vadios. Tradução de Fernanda Bernardo. Coimbra: Palimage, 2009.

DUQUE-ESTRADA, P.C. Derrida e a crítica heideggeriana do humanismo. In: Jacques Derrida: pensar a desconstrução. NASCIMENTO, E. São Paulo: Estação Liberdade, 2005.

FERREIRA, E.; OTTONI, P. Traduzir Derrida: politicas e desconstruções. Campinas: Mercado de Letras, 2006.

GITSHAM, M. (2012). Experiential learning for leadership and sustainability at IBM and HSBC. Journal of Management Development, v.31, n 3, p. 298-307. 
HEUSER, E.M.D. No rastro da filosofia da diferença. Derrida \& a Educação. Belo Horizonte: Autêntica, 2008.

LANS, T.; BLOK, V.; WESSELINK, B. (2013). Renate Wesselink Learning apart and together: towards an integrated competence framework for sustainable entrepreneurship in higher education. Journal of Cleaner Production, xxx, pp. 1-11.

KEARINS, K.; SPRINGETT, S. (2003). Educating for sustainability: Developing critical skills. Journal of Management Education, v.27, nº 2, pp. 188-204.

SANTIAGO, S. Glossário de Derrida. Departamento de Letras da PUC/RJ. Rio de Janeiro: F. Alves, 1976.

SPRINGETT, S. (2003). An 'Incitement to discourse': Benchmarking as a springboard to sustainable development. Business Strategy and the Environment, v. 12, n ${ }^{\circ}$ 2, pp. 1-11.

STAHEL, A. (1994). Capitalismo e Entropia: Os Aspectos Ideológicos de uma Contradição e a Busca de Alternativas Sustentáveis. CAVALCANTI, C. (Org.). In: DESENVOLVIMENTO E NATUREZA: Estudos para uma sociedade sustentável. INPSO/ FUNDAJ, Instituto de Pesquisas Sociais, Fundação Joaquim Nabuco, Ministério de Educação, Governo Federal, Recife, Brasil. Acesso em: 23 Ago.2013.

STONE, D. (2015). The group of 20 transnational policy community: governance networks, policy analysis and think tanks. International Review of Administrative Sciences. v. 81, $\mathrm{n}^{\mathrm{O}} 04$, pp. 793-811.

TATIM, C.T.; GUARESCHI, P.A. (2012) O Nosso Negócio é o Bem Comum: Representações Sociais no Discurso da Empresa Socialmente Sustentável. PSICO. v. $43, \mathrm{n}^{\mathrm{O}} 2$, pp. 147-154.

TILBURY, D.; WORTMAN, D. Engaging people in sustainability. Commission on Education and Communication. IUCN: Gland, Switzerland and Cambridge, UK, 2004.

VINHA, V. G. da. As empresas e o desenvolvimento sustentável: trajetória da construção de uma convenção. In: Peter H. May. (Org.). Economia do Meio Ambiente. 2 ed. Rio de Janeiro: Elsevier, p. 181-204, 2010.

WOlFREYS, J. (2009). Compreender Derrida. Tradução de Caesar Souza. Petrópolis-RJ: Editora Vozes.

Recebido: 20/05/2019

Aceito: 9/01/2020

Publicado: 19/02/2020 